Article

\title{
The Development of a Self-Report Questionnaire on Coping with Cyberbullying: The Cyberbullying Coping Questionnaire
}

\author{
Niels C.L. Jacobs *, Trijntje Völlink, Francine Dehue and Lilian Lechner \\ Faculty of Psychology and Educational Sciences, Open University The Netherlands, Valkenburgerweg \\ 177, PO Box 2960, 6419 AT Heerlen, The Netherlands; E-Mails: trijntje.vollink@ou.nl (T.V.); \\ francien.dehue@ou.nl (F.D.); lilian.lechner@ou.nl (L.L.) \\ * Author to whom correspondence should be addressed; E-Mail: niels.jacobs@ou.nl; \\ Tel.: +31-455-76-2874.
}

Academic Editors: Conor Mc Guckin and Lucie Corcoran

Received: 19 January 2015 / Accepted: 23 April 2015/ Published: 18 May 2015

\begin{abstract}
The negative effects and the continuation of cyberbullying seem to depend on the coping strategies the victims use. To assess their coping strategies, self-report questionnaires (SRQs) are used. However, these SRQs are often subject to several shortcomings: the (single and topological) categorizations used in SRQs do not always adequately differentiate among various coping responses, in addition the strategies of general SRQs fail to accurately measure coping with cyberbullying. This study is therefore aimed to develop a SRQ that specifically measures coping with cyberbullying (i.e., Cyberbullying Coping Questionnaire; CCQ) and to discover whether other, not single and topological, categorizations of coping strategies can be found. Based on previous SRQs used in the (cyber)bullying (i.e., traditional and cyberbullying) literature (i.e., 49 studies were found with three different SRQs measuring coping with traditional bullying, cyberbullying or (cyber)bullying) items and categorizations were selected, compared and merged into a new questionnaire. In compliance with recommendations from the classical test-theory, a principal component analysis and a confirmatory factor analysis were done, and a final model was constructed. Seventeen items loaded onto four different coping categorizations: mental-, passive-, social-, and confrontational-coping. The CCQ appeared to have good internal consistency, acceptable test-retest reliability, good discriminant validity and the development of the CCQ fulfilled many of the recommendations from classical test-theory. The CCQ omits working in single and topological categorizations and measures cognitive, behavioral, approach and avoidance strategies.
\end{abstract}


Keywords: cyberbullying; bullying; traditional bullying; peer victimization; coping; scale; self-report questionnaire; Cyberbullying Coping Questionnaire

\section{Introduction}

Coping has two widely recognized major functions both of which are often represented in stressful encounters: emotion regulation and problem solving. By employing cognitive and behavioral strategies, an individual either reduces, masters or tolerates the internal and external demands that are the consequence of stressful events. According to the transactional model of stress and coping, the choice of these strategies is influenced by appraisals. These are evaluations of how important a situation is to one's well-being and how able one is to cope with, or change the situation [1,2]. Several categories of coping have been suggested, such as problem-focused-, emotion-focused-, passive-, aggressive-, distancing-, or avoidance-coping [3]. In the case of cyberbullying, it appears that the negative consequences are influenced by the use of ineffective coping strategies [4], and the use of ineffective coping appears to keep the online and offline bullying going [5-12]. Worldwide, a lot of adolescents are the victims of cyberbullying [13], and as a result they suffer from a range of negative consequences such as anxiety [14], depression, emotional distress [15,16], suicidality [17,18], school violence and delinquency [19]. For the most part they are also related to traditional bullying [20,21], and, especially, the combination of traditional and cyberbullying (i.e., (cyber)bullying) seems to result in the most mental health and social problems compared to being bullied "only" in one way [22,23]. Hence, insight into (adequate) coping seems highly relevant in the field of cyberbullying.

To assess coping strategies of cyberbullying (and traditional) victims, researchers often use self-report questionnaires (SRQs) in which they ask victims to describe, aggregate or report their coping responses to a general stressor. In general, the use of SRQs has many advantages: it is a low-cost way of conducting research on a large scale, it is the most direct way to assess the construct of coping, it has high(er) apparent validity, and is less time-consuming than conducting interviews [24,25]. However, the current existing SRQs are also subject to several disadvantages. Firstly, in general, researchers agree that coping strategies (i.e., items) cluster into primary coping categories, and that these categories contain either cognitive- versus behavioral-, avoid- versus approach- or problem-focused versus emotion-focused strategies [3,26]. Unfortunately, these single (i.e., problem- versus emotion-focused) and topological (e.g., active versus passive, cognitive versus behavioral, avoid versus approach) categorizations are not optimal categories because coping is likely to serve many functions and is multidimensional [3,27]. For example, avoidance strategies can be both problem-focused and emotion-focused [26], and the coping strategy "justification" is neither an approach nor avoidant style of coping [28]. Hence, there still appears to be a gap between the acknowledged need of researchers to be able to identify categorizations of coping behavior and the development of measures that can distinguish these categorizations. In addition, the lack of consensus about core categories hinder comparing and cumulating results from different studies [3]. For example, some researchers suggest that coping categories should be changed into a more fine-grained distinction of hierarchical arranged coping strategies with the higher order categories 
proximity seeking, mastery and accommodation (e.g., $[3,29,30])$, while other researchers keep using single or topological categorizations (e.g., problem-focused versus emotion-focused coping [4,31]).

Secondly, the vast majority of SRQs are not designed to specifically assess coping with cyberbullying, but are designed to assess coping with stressful events in general. This general coping approach lacks the specificity of coping in bullying situations, because appraisals influence choice of coping strategies [1]. For example, appraising an online situation as harmful can be quite different compared to an offline situation as harmful. The appraisal harmfulness in online name calling (i.e., cyberbullying) appears to depend on knowing the cyberbully in the offline world, on the cyberbully being a member of existing social groups, and on the transfer of cyberbullying to bullying in the offline world [22]. The appraisal of harmfulness in offline bullying may depend on the appearance of, for example the one calling names (e.g., tall versus small) and non-verbal communication. This difference in appraisal can lead to a different choice of coping strategies online (e.g., deleting a message) compared to offline (e.g., fighting back). Similarly, context also seems to play an important role in cyberbullying [32-34], leading an adolescent choosing a different coping strategy online compared to offline.

Other research based on appraisals (e.g., "Is there a threat such as cyberbullying?" and "Do I have the resources to address the cyberbullying?"), has shown that theories such as the transactional model of stress and coping [1] have to be adjusted to include coping strategies specifically for cyberbullying [26]. Online, it seems adolescents choose between reactive coping strategies (i.e., acceptance, avoidance, justification or seeking social support) versus preventive ones (i.e., increase security and awareness, talk in person), instead of between problem-focused versus emotion-focused ones. The appraisal "nothing can be done" leads to the use of other coping strategies (e.g., adopting the belief that there is no way to prevent cyberbullying) compared to the appraisal "something can be done" [26] (e.g., increasing security and awareness) when cyberbullied. Offline, these appraisals could lead to, for example, running away or asking the bully to stop in a confident manner, respectively. Furthermore, many SRQs do not assess concrete "online" coping strategies (e.g., saving evidence by taking a screenshot [35]), and online it might be easier to be passive (i.e., online you can easily delete a message or close a window, offline you cannot). When these "online" coping strategies are not included in a SRQ, possible important strategies are not assessed. Consequently, when currently existing coping SRQs are used to enable, for example tailoring [36], in interventions, these interventions fail to provide participants with specific advice on how to cope more effectively with cyberbullying.

It, thus, seems that coping SRQs used in the cyberbullying literature are subject to two major shortcomings: (1) the (single and topological) categorizations used in existing SRQs do not adequately differentiate among various coping responses; and (2) the strategies of general SRQs do not completely and adequately measure concrete coping with cyberbullying, which make adequate intervention more difficult. Online, it is likely that specific coping strategies - that are part of coping categorizations - exist, such as saving evidence [35], blocking and deleting [33,37,38], contacting service providers [39], and reacting by not actually saying anything [40]. This study therefore aims to develop a new SRQ that specifically measures cyberbullying victims' coping strategies and to discover whether other, not single and topological, categorizations of coping strategies can be found. Underlying this line of reasoning is the transactional model of stress and coping [1] that states that appraisals influence choice of coping strategies. Based on his review, Garcia [41] suggested that a new coping questionnaires should be an adapted and modified version of coping measures that already exists. Therefore, we conducted a 
preliminary study in which we made an overview of all coping SRQs used in the traditional and cyberbullying literature. Based on the items and categorizations found in this overview, and based on multiple recommendations from classical test-theory (see Sveinbjornsdottir and Thorsteinsson [34] for an overview), in the main study the Cyberbullying Coping Questionnaire (CCQ) was developed, with the purpose to find better fitting categorizations of coping strategies for cyberbullying. In the main study, we further tested the CCQ for suitability, reliability and (discriminant) validity.

\section{Preliminary Study: Coping SRQs' Literature Review}

An overview of all coping SRQs used in the traditional and cyberbullying literature is made with categorizations and study information.

\subsection{Materials and Methods}

Google Scholar, PsychINFO and PubMed were used to search for published and peer-reviewed studies, no later than the end of November 2014. The studies were selected on their usage of SRQs to investigate the coping strategies of adolescents in response to (cyber) bullying. The search items included "cyberbullying", "online bullying", "bullying", "traditional bullying", "peer victimization", "coping", "cope", and "scale". Only studies that used an SRQ to measure coping with (cyber)bullying were included. These studies were scanned for scales that measured more than one coping category (e.g., Naylor and Cowie [42] only measured peer support systems and thus was not included). Furthermore, the articles found were scanned for additional references that may not have surfaced in the initial search.

\subsection{Results}

An overview of all SRQs and their characteristics can be found in Table 1. To conclude, forty-nine studies were found that used 35 different SRQs to assess coping with (cyber)bullying: 12 studies used seven SRQs to measure coping with cyberbullying (however, we could not access the following study, [43]); 38 studies used 28 different SRQs to measure coping with traditional bullying (however, we could not access studies [44] and [45]); and three studies used three SRQs to measure coping with both traditional and cyberbullying. In eight studies, a questionnaire was developed or an existing questionnaire was adapted in order to measure coping with cyberbullying specifically. The most often used SRQs to assess coping with cyberbullying were the Adolescent Coping Scale (ACS; [46]) and an adapted version of the Utrechtse Coping List-Adolescents (UCL-A; [47]). The most often used SRQs to assess coping with traditional bullying were the Self-Report Coping Measure (SRCM; [48]) and the Survey for Coping with Rejection Experiences (SCORE; [49]). 
Table 1. Characteristics of self-report coping questionnaires used in (cyber)bullying research among adolescents.

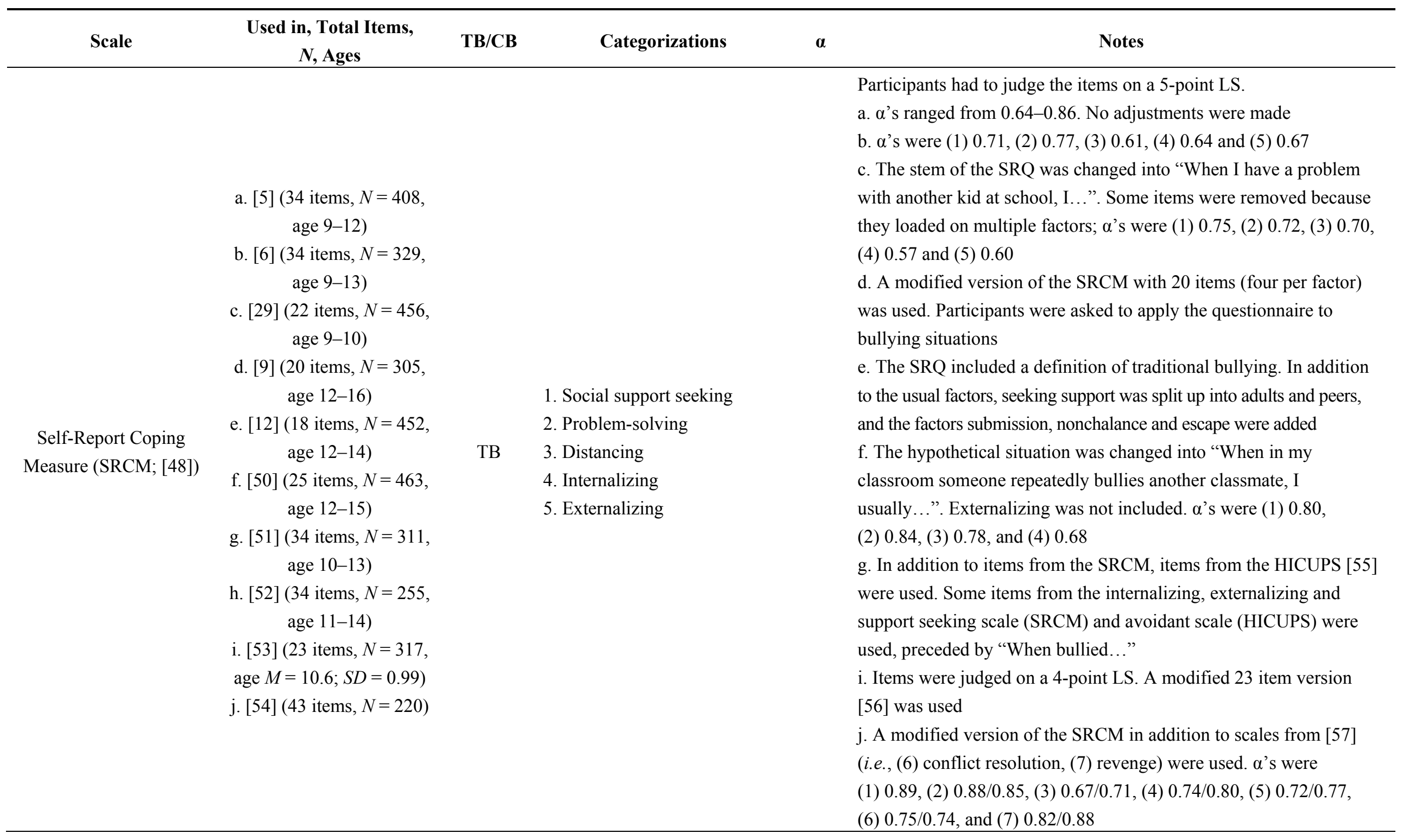


Table 1. Cont.

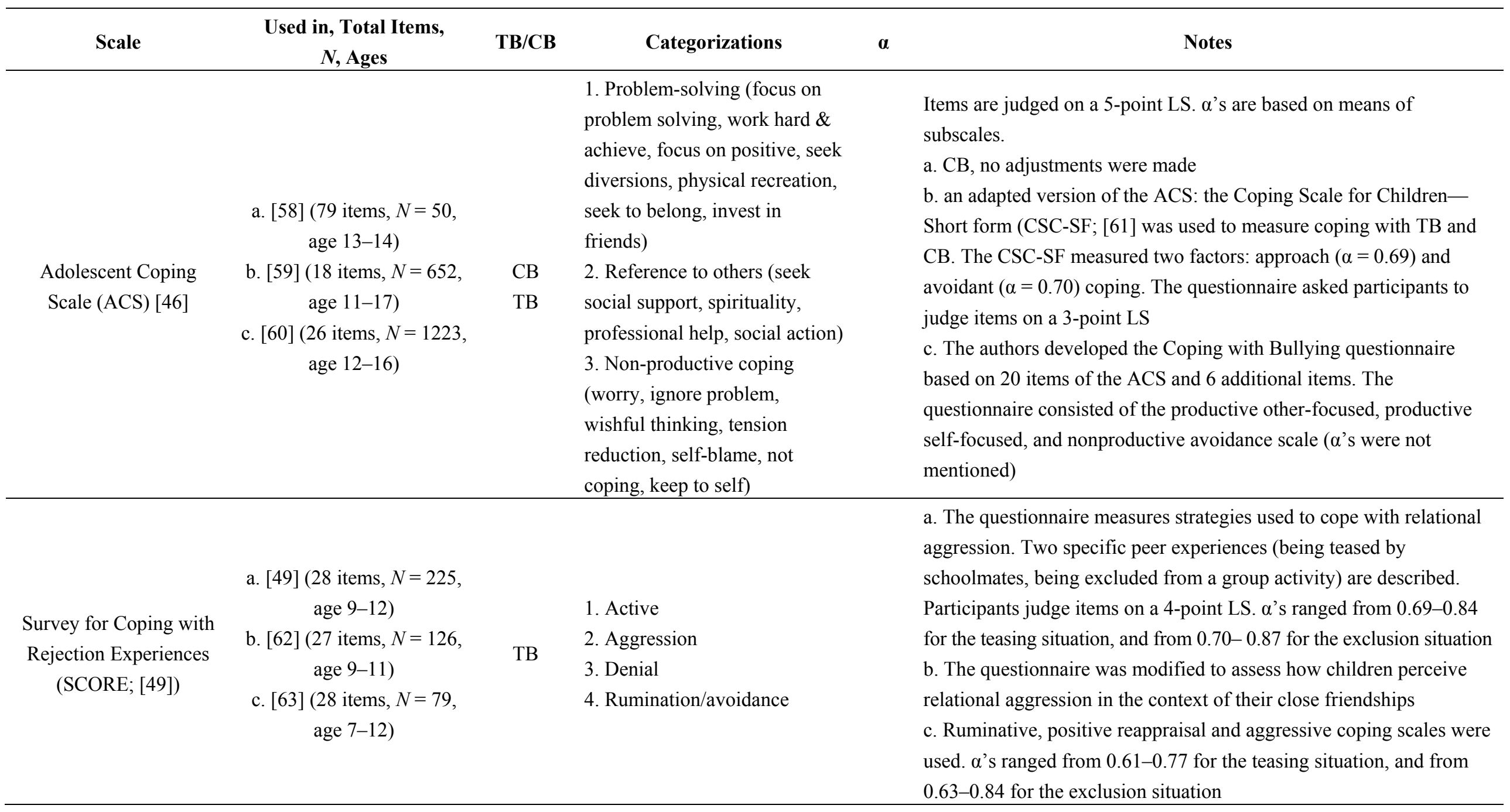


Table 1. Cont

\begin{tabular}{|c|c|c|c|c|c|}
\hline Scale & $\begin{array}{c}\text { Used in, Total Items, } \\
N, \text { Ages }\end{array}$ & TB/CB & Categorizations & $\alpha$ & Notes \\
\hline \multirow{4}{*}{$\begin{array}{l}\text { Utrechtse Coping } \\
\text { List_-Adolescents } \\
\text { (UCL-A; [47]) }\end{array}$} & \multirow{4}{*}{$\begin{array}{l}\text { a. [4] }(24 \text { items, } N=325 \text {, } \\
\text { age } 11-12) \\
\text { b. [31] }(26 \text { items, } N=325 \text {, } \\
\quad \text { age } 11-12)\end{array}$} & \multirow{4}{*}{$\mathrm{CB}$} & $\begin{array}{l}\text { a.1 Problem focused } \\
\text { (confronting, social support) }\end{array}$ & 0.59 & \multirow{4}{*}{$\begin{array}{l}\text { The questionnaire that measures coping with cyberbullying is an } \\
\text { adapted version of the UCL-A, items were rewritten for coping with } \\
\text { cyberbullying, and are judged on a 4-point LS }\end{array}$} \\
\hline & & & $\begin{array}{l}\text { a. } 2 \text { Emotion focused } \\
\text { (palliative, avoidance, } \\
\text { optimistic, express emotions) } \\
\text { b.1 Depressive/emotional } \\
\text { expression }\end{array}$ & 0.91 & \\
\hline & & & b.2.Avoidance/palliative & 0.57 & \\
\hline & & & b.3 Social support seeking & 0.76 & \\
\hline $\begin{array}{l}\text { The Coping Strategy } \\
\text { Indicator (CSI; [64]) }\end{array}$ & $\begin{array}{c}\text { [65] }(33 \text { items, } N=375 \\
\text { age } M=15.98, S D=1.41)\end{array}$ & $\mathrm{CB}$ & $\begin{array}{l}\text { 1. Problem solving } \\
\text { 2. Seeking social support } \\
\text { 3. Avoidance }\end{array}$ & $\begin{array}{l}0.85 \\
0.87 \\
0.69\end{array}$ & $\begin{array}{l}\text { The questionnaire is based on previous measures (e.g., [1] and } \\
\text { suggestions from students and colleagues. Items are judged on a } \\
\text { 3-point LS }\end{array}$ \\
\hline $\begin{array}{l}\text { Cognitive Emotion } \\
\qquad \text { Regulation } \\
\text { Questionnaire-Kids } \\
\text { version(CERQ-k; [66]) }\end{array}$ & $\begin{array}{c}\text { [67] }(36 \text { items, } N=131, \\
\text { age } 9-11)\end{array}$ & TB & $\begin{array}{l}\text { 1. Refocus on planning } \\
\text { 2. Rumination } \\
\text { 3. Putting into perspective } \\
\text { 4. Catastrophizing } \\
\text { 5. Positive refocusing } \\
\text { 6. Positive reappraisal } \\
\text { 7. Acceptance } \\
\text { 8. Self-blame } \\
\text { 9. Other-blame }\end{array}$ & $\begin{array}{l}0.75 \\
0.73 \\
0.68 \\
0.67 \\
0.79 \\
0.67 \\
0.62 \\
0.79 \\
0.79\end{array}$ & $\begin{array}{l}\text { The study initially focused on anxious children. However, } 61 \% \text { of } \\
\text { these experienced bullying. The CERQ-k is an adapted (i.e., } \\
\text { simplified and shortened) version of the CERQ [68]. Participants had } \\
\text { to judge items on a 5-point LS }\end{array}$ \\
\hline
\end{tabular}


Table 1. Cont

\begin{tabular}{|c|c|c|c|c|c|}
\hline Scale & $\begin{array}{c}\text { Used in, Total Items, } \\
N, \text { Ages }\end{array}$ & TB/CB & Categorizations & $\alpha$ & Notes \\
\hline \multirow{6}{*}{$\begin{array}{l}\text { Children's Coping } \\
\text { Strategies Checklist } \\
\quad \text { (CCSC; [69]) }\end{array}$} & \multirow{6}{*}{$\begin{array}{c}{[70](45 \text { items, } N=230} \\
\text { age } 8-13)\end{array}$} & \multirow{6}{*}{$\mathrm{TB}$} & 1. Active & 0.84 & \multirow{6}{*}{$\begin{array}{l}\text { Participants had to judge items on a 4-point LS. The four broad } \\
\text { coping categories consist of: (1) cognitive decision-making, direct } \\
\text { problem solving, positive cognitive restructuring, seeking } \\
\text { understanding; (2) cognitive avoidance, avoidant actions; } \\
\text { (3) distracting actions, physical release of emotions; and } \\
\text { (4) problem-focused support, emotion focused support }\end{array}$} \\
\hline & & & 2. Avoidant & 0.75 & \\
\hline & & & 3. Distraction & 0.63 & \\
\hline & & & & & \\
\hline & & & 4. Support seeking & 0.89 & \\
\hline & & & & & \\
\hline \multirow{4}{*}{$\begin{array}{l}\text { German Coping } \\
\text { Questionnaire for } \\
\text { Children and } \\
\text { Adolescents [71] }\end{array}$} & \multirow{4}{*}{$\begin{array}{c}\text { [72] (36 items, } N=409, \\
\text { age } 10-16)\end{array}$} & \multirow{4}{*}{ TB } & 1. Emotion-focused & 0.69 & \multirow{4}{*}{$\begin{array}{l}\text { Participants had to judge items on a 5-point LS. The three main } \\
\text { scales consisted of nine subscales: (1) minimization, } \\
\text { distraction/recreation; (2) situation control, positive self-instructions, } \\
\text { social support; and (3) passive avoidance, rumination, } \\
\text { resignation, aggression }\end{array}$} \\
\hline & & & 2. Problem-focused & 0.85 & \\
\hline & & & & & \\
\hline & & & 3. Maladaptive & 0.87 & \\
\hline \multirow{4}{*}{$\begin{array}{l}\text { Coping Styles } \\
\text { Questionnaire (CSQ; } \\
\text { [73]) }\end{array}$} & \multirow{4}{*}{$\begin{array}{c}\text { [74] }(48 \text { items, } N=99 \\
\text { age } 18-21)\end{array}$} & \multirow{4}{*}{ TB } & 1. Rational & 0.77 & \multirow{4}{*}{$\begin{array}{l}\text { The CSQ normally consists of } 60 \text { items. In this study, a } 48 \text {-item } \\
\text { version was used in which male participants had to judge items on a } \\
\text { 4-point LS. This study focused on bullying in prisons }\end{array}$} \\
\hline & & & 2. Detached & 0.71 & \\
\hline & & & 3. Emotional & 0.85 & \\
\hline & & & 4. Avoidance & 0.75 & \\
\hline \multirow{4}{*}{$\begin{array}{c}\text { Ways of Coping } \\
\text { Checklist (WCCL; [75]) }\end{array}$} & \multirow{4}{*}{$\begin{array}{c}\text { [8] (35 items, } N=459 \\
\text { age } 9-14)\end{array}$} & \multirow{4}{*}{ TB } & 1. Problem-focused & 0.82 & \multirow{4}{*}{ Participants had to judge item on a 4-point LS } \\
\hline & & & 2. Seek social support & 0.77 & \\
\hline & & & 3. Wishful thinking & 0.73 & \\
\hline & & & 4. Avoidance & 0.28 & \\
\hline
\end{tabular}


Table 1. Cont.

\begin{tabular}{|c|c|c|c|c|c|}
\hline Scale & $\begin{array}{c}\text { Used in, Total Items, } \\
N, \text { Ages }\end{array}$ & $\mathrm{TB} / \mathrm{CB}$ & Categorizations & $\alpha$ & Notes \\
\hline \multirow{5}{*}{$\begin{array}{l}\text { Life Events and Coping } \\
\text { Inventory (LECI; [76]) }\end{array}$} & \multirow{5}{*}{$\begin{array}{l}\text { [77] (52 items, } N=510 \\
\quad \text { age } 10-12)\end{array}$} & \multirow{5}{*}{ TB } & 1. Aggression & 0.81 & \multirow{5}{*}{$\begin{array}{l}\text { Participants had to judge items on a 4-point LS, specifically for } \\
\text { which behaviors they used at school }\end{array}$} \\
\hline & & & 2. Distraction & 0.80 & \\
\hline & & & 3. Self-destruction & 0.77 & \\
\hline & & & 4. Stress-recognition & 0.75 & \\
\hline & & & 5. Endurance & 0.62 & \\
\hline \multirow{2}{*}{$\begin{array}{l}\text { Coping Scale for } \\
\text { Children-Short Form } \\
\text { (CSC-SF; [61]) }\end{array}$} & \multirow{2}{*}{$\begin{array}{c}\text { c. [78] }(16 \text { items, } N=379 \text {, } \\
\text { age } 10-13)\end{array}$} & \multirow[b]{2}{*}{ TB } & 1. Approach & 0.69 & \multirow[b]{2}{*}{ Items had to be rated on a 3-point LS } \\
\hline & & & 2. Avoidant & 0.70 & \\
\hline \multirow{7}{*}{$\begin{array}{l}\text { The Problem-solving } \\
\text { Style Inventory [79] }\end{array}$} & \multirow{7}{*}{$\begin{array}{l}\text { [80] }(28 \text { items, } N=236 \\
\text { age } 12-15)\end{array}$} & \multirow{7}{*}{ TB } & 1. Helplessness & 0.80 & \multirow{7}{*}{ Higher scores mean more positive problem-solving style } \\
\hline & & & 2. Control & 0.71 & \\
\hline & & & 3. Creativity & 0.75 & \\
\hline & & & 4. Confidence & 0.78 & \\
\hline & & & 5. Approach style & 0.73 & \\
\hline & & & 6. Avoidance style & 0.71 & \\
\hline & & & 7. Support-seeking & 0.73 & \\
\hline $\begin{array}{l}\text { Coping Orientation to } \\
\text { Problem Experienced } \\
\text { (COPE; [81]) }\end{array}$ & $\begin{array}{l}\text { [82] (60 items, } N=1339 \\
\text { age 17-29) }\end{array}$ & TB & $\begin{array}{l}\text { 1. Problem-focused } \\
\text { 2. Emotion-focused } \\
\text { 3. Avoidant }\end{array}$ & 0.92 & $\begin{array}{l}\text { Participants judge items on a 4-point LS. Only the } \alpha \text { for the complete } \\
\text { questionnaire was mentioned }\end{array}$ \\
\hline
\end{tabular}


Table 1. Cont

\begin{tabular}{|c|c|c|c|c|c|}
\hline Scale & $\begin{array}{l}\text { Used in, Total Items, } \\
\quad N, \text { Ages }\end{array}$ & $\mathrm{TB} / \mathrm{CB}$ & Categorizations & $\alpha$ & Notes \\
\hline $\begin{array}{l}\text { How I Cope Under } \\
\text { Pressure Scale } \\
\text { (HICUPS; [55]) }\end{array}$ & $\begin{array}{c}{[51] \text { (45 items, } N=311,} \\
\text { age } 10-13)\end{array}$ & TB & $\begin{array}{l}\text { 1. Active } \\
\text { 2. Distraction } \\
\text { 3. Avoidance } \\
\text { 4. Support Seeking }\end{array}$ & $\begin{array}{c}0.88 \\
- \\
0.65 \\
0.86\end{array}$ & $\begin{array}{l}\text { Six items based on the avoidant actions subscale were used. } \\
\text { Participants judged these items on a 5-point LS. Information about } \\
\text { the scales, } \alpha \text { 's and ages were found in [55] }\end{array}$ \\
\hline $\begin{array}{c}\text { Revised Ways of } \\
\text { Coping (RWC; [83]) }\end{array}$ & $\begin{array}{l}\text { [84] }(66 \text { items, } N=98 \\
\text { grade } 6-12)\end{array}$ & TB & $\begin{array}{l}\text { 1. Problem-focused } \\
\text { 2. Wishful thinking } \\
\text { 3. Detachment } \\
\text { 4. Seeking social support } \\
\text { 5. Focusing on the positive } \\
\text { 6. Self-blame } \\
\text { 7. Tension reduction } \\
\text { 8. Keep to self }\end{array}$ & & $\begin{array}{l}\text { The questionnaire measures styles used in relation to a } \\
\text { distinguishable event. In this study, all participants were girls. They } \\
\text { were asked to judge the items on a 4-point LS for relational } \\
\text { aggression. } \alpha \text { 's ranged from } 0.59-0.88\end{array}$ \\
\hline$* *$ & $\begin{array}{c}\text { [85] (29 items, } N=573 \\
\text { age } 12-13)\end{array}$ & TB & $\begin{array}{l}\text { 1. Counter aggression } \\
\text { 2. Helplessness } \\
\text { 3. Nonchalance }\end{array}$ & $\begin{array}{l}0.87 \\
0.75 \\
0.77 \\
\end{array}$ & $\begin{array}{l}\text { Participants were asked to indicate on a 3-point LS how victims } \\
\text { (including themselves) fit the situations. Two situations were dropped } \\
\text { from the scale }\end{array}$ \\
\hline $\begin{array}{l}\text { Children's Emotional } \\
\text { Dysregulation } \\
\text { Questionnaire (CEDQ)* }\end{array}$ & $\begin{array}{l}\text { [52] }(9 \text { items, } N=255 \\
\text { age } 11-14)\end{array}$ & TB & $\begin{array}{l}\text { 1. Anger } \\
\text { 2. Sadness } \\
\text { 3. Fear }\end{array}$ & $\begin{array}{l}0.71 \\
0.72 \\
0.76\end{array}$ & $\begin{array}{l}\text { Participants judge items on a 5-point LS. Higher scores reflect greater } \\
\text { emotional dysregulation }\end{array}$ \\
\hline
\end{tabular}


Table 1. Cont

\begin{tabular}{|c|c|c|c|c|c|}
\hline Scale & $\begin{array}{c}\text { Used in, Total Items, } \\
N, \text { Ages }\end{array}$ & TB/CB & Categorizations & $\alpha$ & Notes \\
\hline$* *$ & $\begin{array}{c}{[86](9 \text { items, } N=394} \\
\text { age } M=16.4, S D=1.09)\end{array}$ & $\mathrm{TB}$ & $\begin{array}{l}\text { 1. Avoidance } \\
\text { 2. Health behavior } \\
\text { 3. Increased eating }\end{array}$ & $\begin{array}{l}0.73 \\
0.80 \\
0.80\end{array}$ & $\begin{array}{l}\text { This study focused on weight-based victimization. Participants were } \\
\text { asked to judge } 28 \text { items on a 5-point LS. A subset of nine items was } \\
\text { used }\end{array}$ \\
\hline$* *$ & $\begin{array}{c}\text { [87] }(10 \text { items, } N=509, \\
\text { age } 11-14)\end{array}$ & TB & $\begin{array}{l}\text { 1. Problem focused } \\
\text { 2. Seeking social support } \\
\text { 3. Attending positive life } \\
\text { events }\end{array}$ & 0.92 & $\begin{array}{l}\text { Participants were asked to indicate how often each strategy (i.e., } \\
\text { item) helped when being picked upon (based on [88]). } \alpha \text { was only } \\
\text { provided for the whole scale }\end{array}$ \\
\hline$* *$ & $\begin{array}{c}{[89](14 \text { items, } N=765,} \\
\text { age } M=13.18, S D=0.63)\end{array}$ & $\mathrm{CB}$ & $\begin{array}{l}\text { 1. Distant advice } \\
\text { 2. Assertiveness } \\
\text { 3. Helplessness } \\
\text { 4. Close support } \\
\text { 5. Retaliation }\end{array}$ & $\begin{array}{c}0.67 \\
0.49 \\
0.36 \\
0.65 \\
- \\
\end{array}$ & $\begin{array}{l}\text { Items were based on the results of a qualitative pilot study [90]. } \\
\text { Students were asked what a hypothetical victim would do in a } \\
\text { situation (situations varied between students) and had to rate the } 14 \\
\text { items on a 4-point LS }\end{array}$ \\
\hline $\begin{array}{l}\text { Items from LAPSuS } \\
\text { project }[91]\end{array}$ & $\begin{array}{c}\text { [92] }(11 \text { items, } N=1987 \\
\text { age } 6-19)\end{array}$ & $\begin{array}{l}\mathrm{CB} \\
\mathrm{TB}\end{array}$ & $\begin{array}{l}\text { 1. Aggressive } \\
\text { 2. Helpless } \\
\text { 3. Cognitive } \\
\text { 4. Technical }\end{array}$ & & $\begin{array}{l}\text { Items were not specific for cyberbullying, participants were asked to } \\
\text { rate the items on a 4-point LS with in mind being cyberbullied, } \\
\text { physically or verbally bullied. The model had to be rejected (bad fits } \\
\text { on RMSEA and Chi square test) }\end{array}$ \\
\hline$* *$ & $\begin{array}{c}\text { [93] }(26 \text { items, } N=2092 \\
\text { age } 12-18)\end{array}$ & $\mathrm{CB}$ & $\begin{array}{l}\text { 1. Technological coping } \\
\text { 2. Reframing } \\
\text { 3. Ignoring } \\
\text { 4. Dissociation } \\
\text { 5. Cognitive avoidance } \\
\text { 6. Behavioral avoidance } \\
\text { 7. Seeking support } \\
\text { 8. Confrontation } \\
\text { 9. Retaliation }\end{array}$ & - & $\begin{array}{l}\text { List of coping strategies was developed based on extensive literature } \\
\text { review on coping strategies in general and coping strategies in } \\
\text { cyberbullying. Classification was based on [94]. Participants } \\
\text { indicated yes, no, or not applicable for each item }\end{array}$ \\
\hline
\end{tabular}


Table 1. Cont

\begin{tabular}{|c|c|c|c|c|c|}
\hline Scale & $\begin{array}{c}\text { Used in, Total Items, } \\
N \text {, Ages }\end{array}$ & TB/CB & Categorizations & $\alpha$ & Notes \\
\hline$* *$ & $\begin{array}{c}{[95](16 \text { items, } N=830} \\
\text { age } 8-14)\end{array}$ & TB & - & - & $\begin{array}{l}\text { Participants had to judge a list of } 16 \text { items on a 4-point LS (except for } \\
\text { items related to making new friends). Items were based on coping } \\
\text { responses validated in previous research }\end{array}$ \\
\hline $\begin{array}{l}\text { Questionnaire of } \\
\text { Cyberbullying (QoCB)* }\end{array}$ & $\begin{array}{l}\text { [38] }(21 \text { items, } N=269 \\
\text { age } 12-19)\end{array}$ & $\mathrm{CB}$ & - & - & $\begin{array}{l}\text { A number of questions multiple-choice questions measured blocking } \\
\text { the message or person, telling person to stop harassing, changing } \\
\text { usernames, telling friends, telling parents, telling teachers, ignoring } \\
\text { and not telling anyone }\end{array}$ \\
\hline$* *$ & $\begin{array}{l}\text { [96] }(11 \text { items, } N=571 \\
\text { all ages) }\end{array}$ & $\mathrm{CB}$ & - & - & Participants had to indicate yes or no for each behavior \\
\hline$* *$ & $\begin{array}{l}\text { [97] }(4 \text { items, } N=548 \\
\text { age }<25)\end{array}$ & $\mathrm{CB}$ & - & - & $\begin{array}{l}\text { The questionnaire included items on offline and online coping } \\
\text { strategies. Participants were asked to indicate which } \\
\text { strategy/strategies they had used, and how helpful these strategies } \\
\text { were on a 3-point LS }\end{array}$ \\
\hline$* *$ & $\begin{array}{l}{[98](10 \text { items, } N=219} \\
\quad \text { age } 18-40)\end{array}$ & $\mathrm{TB}$ & - & - & $\begin{array}{l}\text { Participants were asked to indicate which of } 10 \text { coping strategies they } \\
\text { have used (e.g., I talked to the bullies, I tried to ignore it) in response } \\
\text { to TB }\end{array}$ \\
\hline$* *$ & $\begin{array}{l}\text { [7] (12 items, } N=1852, \\
\text { age } 4-19)\end{array}$ & TB & - & - & $\begin{array}{l}\text { Participants had to indicate which of the } 12 \text { given strategies they have } \\
\text { used in responding to TB }\end{array}$ \\
\hline$* *$ & $\begin{array}{l}\text { [99] }(3 \text { items, } N=207 \\
\text { age } 13-14)\end{array}$ & TB & - & - & $\begin{array}{l}\text { For each type of bullying (physical, verbal, social), participants first } \\
\text { had to give an open answer about-And then had to choose a coping } \\
\text { strategy from a list of eight to ten strategies and indicate how useful } \\
\text { this strategy was }\end{array}$ \\
\hline$* *$ & $\begin{array}{l}{[100](1 \text { items, } N=2308} \\
\text { age } 10-14)\end{array}$ & TB & - & - & $\begin{array}{l}\text { Participants were asked "What did you usually do when you were } \\
\text { bullied at school?" }\end{array}$ \\
\hline
\end{tabular}


Table 1. Cont.

\begin{tabular}{|c|c|c|c|c|c|}
\hline Scale & $\begin{array}{l}\text { Used in, Total Items, } \\
\quad N \text {, Ages }\end{array}$ & TB/CB & Categorizations & $\alpha$ & Notes \\
\hline$* *$ & [101] $(N=348$, age $9-11)$ & TB & - & - & $\begin{array}{l}\text { The questionnaire was based on previous studies. Participants were } \\
\text { asked to indicate on a checklist which coping behaviors they } \\
\text { displayed }\end{array}$ \\
\hline$* *$ & $\begin{array}{c}{[102](N=1835} \\
\quad \text { age } 11-14)\end{array}$ & TB & - & - & $\begin{array}{l}\text { Participants were asked to name all coping strategies they have used } \\
\text { in response to TB. Later, these answers were coded independently by } \\
\text { two authors }\end{array}$ \\
\hline $\begin{array}{l}\text { Internet Experiences } \\
\text { Questionnaire (IEQ)* }\end{array}$ & {$[103](N=856$, age $16-24)$} & $\mathrm{CB}$ & - & - & $\begin{array}{l}\text { Participants could select as many options as applicable to adequately } \\
\text { describe their behavioral reactions }\end{array}$ \\
\hline$* *$ & [104] (7 items, $N=323)$ & TB & - & - & $\begin{array}{l}\text { Participants were asked to indicate on a 3-point LS what they would } \\
\text { do in response to being hit, teased, or left out of activities. Four items } \\
\text { were adapted from [105], the other items came from the literature }\end{array}$ \\
\hline
\end{tabular}




\section{Main Study: Developing and Testing the CCQ}

Based on the overview of coping SRQs from the preliminary study, the Cyberbullying Coping Questionnaire (CCQ) was developed with the purpose of formulating better fitting categorizations of coping strategies for cyberbullying.

\subsection{Materials and Methods}

The following will be described: the procedure of selecting items, constructing the questionnaire, and analyzing the CCQ for suitability, reliability and (discriminant) validity. During this process, the following recommendations that are based on classical test-theory for the development of a psychological test were leading (see [34]): (1) test items must be clear, short, contain one statement, and are easy to understand; (2) a criterion of four items per factor should be used, and twice as many items as will be included in the final version are needed; (3) a minimum of 10 participants per item and a minimum of 500 participants should be used; (4) factor structure should be determined with factor analysis (FA) using oblique rotation; (5) the scree-test should be used in combination with parallel analysis (PA) to determine the amount of extracting factors. The factor loadings should be at least 0.30 when $N \leq 500,0.25$ when $N \leq 1000$, and inter-item correlation should lie between 0.20 and 0.40 ; (6) when the sample is at least 100 , test-retest correlation $\leq 0.70$ for a four-week interval, $\leq 0.60$ for a four- to ten-week interval, and $\leq 0.50$ for an interval longer than ten weeks; (7) concurrent validity $\leq 0.70$ unless scales are of poor quality, and replication through either Exploratory Factor Analysis (EFA) cross-validation or Confirmatory Factor Analysis (CFA) is proven when $90 \%$ of items and factor structures hold (given $N \leq 500$ ); (8) second-order Factor Analysis (FA) is safely conducted if earlier FA used oblique rotation and scree-tests; and (9) tests should consist of 20-50 items.

\subsubsection{Item Selection}

Based on Table 1, the shortcomings mentioned in the introduction, and the recommendations of Sveinbjornsdottir and Thorsteinsson [34], four adolescent coping SRQs were selected as item pools for the CCQ. The UCL-A (1) and a SRQ which assesses coping with cyberbullying (2) were selected because: (a) the UCL-A was used in cyberbullying research [4,31], (b) the SRQ that assesses coping with cyberbullying was based on the UCL-A, and (c) both instruments assess cognitive and behavioral problem-focused coping, cognitive and behavioral emotion-focused coping and depressive/emotional coping with a low number of items (i.e., 24/26 items). The CERQ (3) was selected because: (a) its diversity in different coping categories (i.e., nine different scales) in combination with the low number of items (i.e., 36); and (b) in contrast to other SRQs, it assesses one's cognitions after experiencing a negative event and it assesses how these cognitions are used in emotion-regulation [106]. The ACS (4) was selected because: (a) it was the most often used SRQ in the cyberbullying literature; (b) it was also used in traditional bullying literature; (c) it includes a non-productive scale and a reference to other scales; and (d) it also has a short form (i.e., CSC-SF). Drawbacks of this latter scale, however, are the lack of important information on the development, and some poor psychometric properties (e.g., poor choices of item selection, FA model and rotation, not meeting accepted criteria, and missing of important reliability and validity analysis [34]). 
The first two authors of this paper compared all items from the above-mentioned four adolescent coping SRQs with each other and merged and/or deleted items that appeared to measure the same. Next, these items were transformed to cyber specific situations (e.g., "I ask for help" was changed into "I ask for help on an Internet forum").

\subsubsection{Initial Scale Construction (Preliminary PCA to Reduce Number of Items)}

Construction of the CCQ followed. Selected items were compared with the items and coping categories from the COPE, SRCM, LECI, GCQCA, WCCL and SRCS for completeness. Items that appeared to measure the same strategy were merged into one item. This resulted in 65 items that had to be rated on a 5 -point Likert scale $(1=$ never; 2 =sometimes; 3 =regularly; $4=$ often; $5=$ almost always $)$. As an introduction to the questionnaire, participants were told: In this questionnaire, cyberbullying is bullying via the Internet and via mobile phones. Do you react to cyberbullying? For each sentence, indicate whether you "never", "sometimes", "regularly", "often", or "almost always" did this. In several focus group interviews (i.e., partly described and published in [40], partly described in an internal report [107]), adolescents from the target population indicated that they do not like to read a lot and prefer short questionnaires. In addition, the CCQ was going to be used to tailor the online tailored advice sessions of Online Pestkoppenstoppen (the intervention aims to teach cyberbullying victims how to cope more effectively with cyberbullying [108]) to the aggressive or passive coping strategies used by cyberbullying victims. Several preliminary (not published) PCAs were conducted based on data from 278 adolescents (age $15-22, M=17.54, S D=1.38 ; 89.9 \%$ female) in order to try and find a three-factor structure (i.e., aggressive-, passive-, and active coping), and in order to reduce the number of items as much as possible. After a first preliminary PCA, four items were deleted due to low correlations with other items, 16 items were deleted due to factor loadings on multiple factors or no or insufficient loadings, and two items were deleted due to high skewness values. Based on discussions between the first three authors of this article, three items were added in order to better measure active coping, and three items were merged into one item (that all measured retaliating). Consequently, 44 items were used in a second preliminary PCA. Eight items were deleted due to factor loadings on multiple factors or no or insufficient loadings, and four groups of items were merged into one factor, leading to the deletion of five items. After reviewing the found factor structure, four items were added, again, based on discussions between the authors (i.e., improve the active coping factor). Finally, 35 items remained (see Table 2) that were used for the second principal component analysis (PCA) that is described below.

Table 2. Overview of questions of Cyberbullying Coping Questionnaire (CCQ).

\begin{tabular}{cc}
\hline Item No. & Item Content \\
\hline Item 1 & I wait for the cyberbullying to stop \\
Item 2 & I ask for help on a forum \\
Item 3 & I focus on solving the cyberbullying problem immediately \\
Item 4 & I vent my emotions to myself \\
Item 5 & I think that other people are experiencing things that are much worse \\
Item 6 & I tell the cyberbullies when their behavior is bothering me \\
Item 7 & I think the cyberbullying event will make me a "stronger" person \\
\hline
\end{tabular}


Table 2. Cont.

\begin{tabular}{lc}
\hline Item No. & Item Content \\
\hline Item 8 & I retaliate by cyberbullying \\
Item 9 & I try not to think about the cyberbullying \\
Item 10 & I think that the cyberbullying is not hurting me personally \\
Item 11 & I try to find a new way to stop the cyberbullying \\
Item 12 & I express my feelings \\
Item 13 & I think that I cannot change anything about the cyberbullying event \\
Item 14 & I laugh about the cyberbully/event \\
Item 15 & I delete the message from my profile or e-mail \\
Item 16 & I constantly think how terrible the cyberbullying is \\
Item 17 & I let the cyberbullying happen without reacting \\
Item 18 & I try to find the cause of the cyberbullying \\
Item 19 & I act as if the cyberbullying did not happen \\
Item 20 & I throw or break stuff \\
Item 21 & I contact the people behind the website \\
Item 22 & I think that there are worse things in life \\
Item 23 & I think that the cyberbullying will stop \\
Item 24 & I talk about the cyberbullying event with friends, family or someone I trust \\
Item 25 & I weep with grief \\
Item 26 & I save print screens, messages and text messages as evidence \\
Item 27 & I think about fun things that are not related to cyberbullying \\
Item 28 & I ignore the cyberbullies \\
Item 29 & I ask someone (parent, teacher, friend, peer) for help \\
Item 30 & I cannot think about anything else than being cyberbullied \\
Item 31 & I tell the cyberbullies to stop \\
Item 32 & I joke about the cyberbullying event \\
Item 33 & I think about which steps I need to take to stop the cyberbullying \\
Item 34 & Item 35
\end{tabular}

\subsubsection{Participants}

The baseline data obtained for the intervention study on Online Pestkoppenstoppen [108] was used for the PCA and confirmatory factor analysis (CFA), consisting of 211 participants (62.6\% female) with mean age $12.56(\mathrm{SD}=0.65)$. Of all participants, $31.28 \%$ was a victim, while $67.30 \%$ was a bully/victim (3 missing values). Furthermore, 92.9\% indicated attending lower level educational school (vocational, theoretical, mixed or special needs). In order to be able to calculate test-retest reliability, the second wave of measurements (after a month) was used, in which 68 participants $(80.9 \%$ female) with mean age $12.40(\mathrm{SD}=1.69)$ remained.

\subsubsection{Analysis}

Although some researchers suggest that a coping questionnaire should be developed through using FA rather than PCA [34,109], Field [110] states that the procedure and solutions of PCA and FA differ little from each other. Furthermore, PCA is a psychometrically sound procedure, and it is conceptually 
less complex then FA. The aim of the PCA in this study was to identify groups or clusters of items that measure new, not single or topological, categorizations among the items of the CCQ. Additionally, CFA was used to test the models found in the PCA. SPSS 20 was used for the PCA, to calculate bivariate correlations (of participants' scores on each found categorization of the CCQ) between the first and second wave of measurement (i.e., test-rest reliability) and bivariate correlations between participants' scores on the found categorizations and scores on the Rosenberg Self-Esteem Scale (i.e., RSE, [111]) (i.e., discriminant validity). $\mathrm{R}$ was used to conduct the CFAs and to compute Cronbach's alpha, omega and the greatest lower bound.

\subsection{Results}

\subsubsection{Principal Components Analysis}

Prior to performing the Principal Component Analysis (PCA), the suitability of the data for factor analysis was checked. Seven items (i.e., item 8, 14, 20, 21, 30, 32 and 33; Table 2) were removed due to high skewness values $(\geq 2)$ as well as low variance across response options $[112,113]$. Furthermore, seven items were deleted due to low correlation $(r=<0.3)$ with other items (i.e., item 4, 7, 10, 12, 13, 15 and 25). Because of the ordinal measurement level, a nonlinear principal component analysis (NPCA) was conducted with optimal scaling (i.e., categories of ordered or unordered (discrete) variables are assigned with numeric values [114]). However, many of the variables showed a (roughly) linear transformation (i.e., making numeric treatment possible). The remaining 21 items were therefore analyzed with a PCA. The Kaiser-Meyer-Olkin (KMO) measure verified the sampling adequacy for the analysis, $\mathrm{KMO}=0.82$, and all $\mathrm{KMO}$ values for individuals were $>0.71$ [110]. Bartlett's test of sphericity, $\chi^{2}(210)=1367.11, p<0.001$, indicated that correlations between items were sufficiently large for PCA.

The PCA revealed five components with eigenvalues exceeding Kaiser's criterion of one. These components explained $56.54 \%$ of the variance. Based on the relatively small sample size, parallel analysis and the scree plot's inflexions (i.e., a graph of each eigenvalue ( $Y$-axis) plotted against the factor with which it is associated $(X$-axis)), it was decided to retain four components. The four-component solution explained $51.47 \%$ of the variance. To aid in interpretation an oblique (direct oblimin) rotation was performed [115] and the pattern (i.e., factor loadings/regression coefficients for each variable on each factor) and structure (i.e., correlation coefficients between each variable and factor) matrixes were checked [110]. Item 22 and item 34 were removed based on similar loadings on two factors in the structure and pattern matrix, and item 16 was removed based on too low loadings on the patterns matrix and similar loadings on the structure matrix. Consequently, item 2 had to be removed due to too low correlations to other items.

A third PCA was conducted with 17 items. The Kaiser-Meyer-Olkin measure verified the sampling adequacy for the analysis, $\mathrm{KMO}=0.81$, and all $\mathrm{KMO}$ values for individuals were $>0.69$ [110]. Bartlett's test of sphericity, $\chi^{2}(136)=1058.72, p<0.001$, indicated that correlations between items were sufficiently large for PCA. Five components had eigenvalues over Kaiser's criterion of one. They explained $62.53 \%$ of the variance. Given Kaiser's criterion, parallel analysis and the scree plot's inflexion, five components were retained. However, the oblique rotation failed to converge in 
25 iterations, therefore four components were retained in the final analysis that explained $56.47 \%$ of the variance.

To aid in the interpretation of these four components, an oblique (direct oblimin) rotation was performed. The rotation revealed that the four components showed a number of strong loadings. Table 3 shows the components loadings after rotation, communalities and reliabilities. The items that cluster on the same components suggest that component 1 represents mental coping (i.e., items $3,5,9,11,18$ ), component 2 represents passive coping (i.e., items 1, 17, 19, 23, 27, 28), component 3 represents social coping (i.e., items $24,26,29$ ) and component 4 represents confrontational coping (i.e., items 6, 31, 35). There were moderate correlations (component 1 and 2: $r=0.15$; component 2 and 3: $r=0.13$; component 3 and $4: r=0.22$; component 1 and $3: r=0.27$; component 1 and $4: r=0.27$; component 2 and $4: r=0.04$ ) between components. 
Table 3. Summary of exploratory factor analysis with direct oblimin rotation for the Cyberbullying Coping Questionnaire (CCQ) thoughts questionnaire $(\mathrm{N}=211)$.

\begin{tabular}{|c|c|c|c|c|c|c|c|c|c|}
\hline \multirow[t]{2}{*}{ Item } & \multicolumn{4}{|c|}{ Pattern Coefficients } & \multicolumn{4}{|c|}{ Structure Coefficients } & \multirow[t]{2}{*}{ Communalities } \\
\hline & $\begin{array}{l}\text { Mental } \\
\text { Coping } \\
\end{array}$ & $\begin{array}{l}\text { Passive } \\
\text { Coping } \\
\end{array}$ & Social Coping & $\begin{array}{c}\text { Confrontational } \\
\text { Coping } \\
\end{array}$ & $\begin{array}{l}\text { Mental } \\
\text { Coping } \\
\end{array}$ & $\begin{array}{l}\text { Passive } \\
\text { Coping } \\
\end{array}$ & $\begin{array}{c}\text { Social } \\
\text { Coping } \\
\end{array}$ & $\begin{array}{c}\text { Confrontational } \\
\text { Coping } \\
\end{array}$ & \\
\hline 9 & 0.729 & 0.248 & -0.057 & -0.148 & 0.711 & 0.343 & 0.138 & 0.043 & 0.589 \\
\hline 3 & 0.695 & -0.025 & 0.160 & 0.051 & 0.748 & 0.102 & 0.355 & 0.270 & 0.588 \\
\hline 11 & 0.660 & 0.034 & 0.083 & 0.263 & 0.712 & 0.132 & 0.157 & 0.422 & 0.572 \\
\hline 18 & 0.619 & -.091 & 0.337 & -0.064 & 0.679 & 0.044 & 0.476 & 0.172 & 0.566 \\
\hline 5 & 0.583 & 0.026 & 0.019 & 0.299 & 0.672 & 0.128 & 0.246 & 0.460 & 0.537 \\
\hline 19 & 0.193 & 0.742 & -0.068 & -0.124 & 0.256 & 0.758 & 0.055 & -0.058 & 0.616 \\
\hline 17 & -0.159 & 0.738 & 0.188 & -0.234 & -0.060 & 0.731 & 0.191 & -0.206 & 0.633 \\
\hline 28 & -0.195 & 0.722 & -0.004 & 0.343 & 0.003 & 0.706 & 0.116 & 0.318 & 0.618 \\
\hline 23 & 0.143 & 0.599 & -0.034 & 0.149 & 0.263 & 0.621 & 0.116 & 0.202 & 0.435 \\
\hline 1 & 0.153 & 0.544 & 0.093 & -0.136 & 0.223 & 0.574 & 0.176 & -0.054 & 0.371 \\
\hline 27 & 0.052 & 0.437 & 0.057 & 0.394 & 0.238 & 0.468 & 0.216 & 0.438 & 0.402 \\
\hline 26 & -0.169 & 0.142 & 0.783 & 0.004 & 0.063 & 0.220 & 0.757 & 0.138 & 0.614 \\
\hline 29 & 0.150 & 0.022 & 0.748 & 0.016 & 0.358 & 0.144 & 0.795 & 0.223 & 0.655 \\
\hline 24 & 0.210 & -0.002 & 0.699 & 0.061 & 0.414 & 0.124 & 0.769 & 0.272 & 0.641 \\
\hline 6 & 0.198 & -0.034 & -0.070 & 0.740 & 0.371 & 0.015 & 0.142 & 0.776 & 0.637 \\
\hline 31 & -0.004 & 0.049 & 0.277 & 0.719 & 0.269 & 0.113 & 0.442 & 0.781 & 0.689 \\
\hline 35 & 0.110 & -0.209 & 0.365 & 0.412 & 0.286 & -0.129 & 0.458 & 0.514 & 0.438 \\
\hline Eigen values & 4.69 & 2.34 & 1.39 & \multicolumn{6}{|c|}{1.18} \\
\hline$\%$ of variance & 27.59 & 13.77 & 8.15 & \multicolumn{6}{|c|}{6.97} \\
\hline$\alpha$ & 0.77 & 0.73 & 0.73 & \multicolumn{6}{|c|}{0.68} \\
\hline$\Omega$ & 0.77 & 0.73 & 0.75 & \multicolumn{6}{|c|}{0.7} \\
\hline GLB & 0.77 & 0.79 & 0.76 & \multicolumn{6}{|c|}{0.73} \\
\hline
\end{tabular}

Note: Factor loadings over 0.40 appear in bold; GLB = Greatest Lower Bound. 


\subsubsection{Confirmatory Factor Analysis}

To test whether PCA's structure of coping strategies (i.e., the model) really fits the data, a CFA was conducted by using the statistical program R. Model fit was assessed using the Maximum Likelihood (ML) estimator with the following fit indices [116,117]: (1) chi square $\left(\chi^{2}\right)$ with non-significant values reflecting good fit [118]; (2) the relative chi-square ( $\left.\chi^{2} / \mathrm{df}\right)$ lower than 2 [119]; (3) the Comparative Fit Index (CFI) and the Tucker Lewis Index (TLI) with values larger than 0.90 [112,120]; (4) the Root Mean Square Error of Approximation (RMSEA) with values smaller than 0.06 (values between 0.08 and 0.1 are mediocre and values above 0.1 are poor [117]); and (5) the Standardized Root Mean Square Residual (SRMR) with values lower than 0.08 indicate an acceptable fit [117].

The evaluation of the model fit was not satisfactory for most fit indices (see Table 4 first row) suggesting a rejection of the model. However, modification indices (MIs; indicating how to improve the model) clearly indicate that item 17 ("I let the cyberbullying happen without reacting") and item 7 ("I think about fun things that are not related to cyberbullying") should also load on the mental coping factor, which is plausible since both items can be strategies with a positive effect as well as mental strategies. In addition, MIs indicate that item 9 ("I try not to think about the cyberbullying") should also load on the passive coping factor, which is plausible since this item also expresses a degree of being passive.

Finally, MIs indicate that item 9 ("I try not to think about the cyberbullying") and 19 ("I act as if the cyberbullying did not happen") should correlate with each other, which is also plausible since both items in a way measure ignoring the cyberbullying. After modifying the model, the fit indices are all acceptable (however, RMSEA is not significant anymore) (see Table 3 second row). Furthermore, this model is significantly better fitting than a 1 -factor model $\left(\Delta \chi^{2}(9)=294.1, p<0.001\right.$; see Table 4$)$. The final model is displayed in Figure 1, and its reliabilities in Table 5.

Table 4. Fit indices for first and second solution of Confirmatory Factor Analysis (CFA).

\begin{tabular}{cccccccccc}
\hline Model & $\chi^{2}$ & $d f$ & $\chi^{2} / d f$ & $\Delta \chi^{2}$ & $\Delta d f$ & CFI & TLI & RMSEA & SRMR \\
\hline \multirow{2}{*}{ 1st solution } & $240.16^{* * *}$ & 113 & 2.13 & - & - & 0.868 & 0.841 & $0.073 * *($ CI $90 \%:$ & $0.060-0.086)$ \\
& & & & & & & & 0.079 \\
\multirow{2}{*}{ 2nd solution } & $189.87^{* * *}$ & \multirow{2}{*}{109} & \multirow{2}{*}{1.74} & $294.1^{* * *}$ & 9 & 0.916 & 0.895 & $\begin{array}{c}0.059(\mathrm{CI} 90 \%: \\
0.045-0.073)\end{array}$ & 0.058 \\
\hline
\end{tabular}

Note: $* * * p<0.001 ; * * p<0.01 ; N=223 ; \mathrm{CI}=$ Confidence Interval.

Table 5. (Test-retest) reliabilities of the CFA model.

\begin{tabular}{ccccc}
\hline Coping categories & $\boldsymbol{\alpha}$ & $\boldsymbol{\Omega}$ & GLB & Test-retest $\boldsymbol{r}$ \\
\hline Mental coping & 0.7 & 0.72 & 0.74 & $0.65 *$ \\
Passive coping & 0.73 & 0.73 & 0.8 & $0.47 *$ \\
Social coping & 0.73 & 0.75 & 0.76 & $0.74 *$ \\
Confrontational coping & 0.68 & 0.7 & 0.73 & $0.60 *$ \\
\hline
\end{tabular}

Note: $* p<0.01$. 


\subsubsection{Test-Retest Reliability}

A test-retest reliability of at least 0.60 was expected for a four to ten week interval [34]. See Table 5 for test-retest reliabilities for an interval of a month.

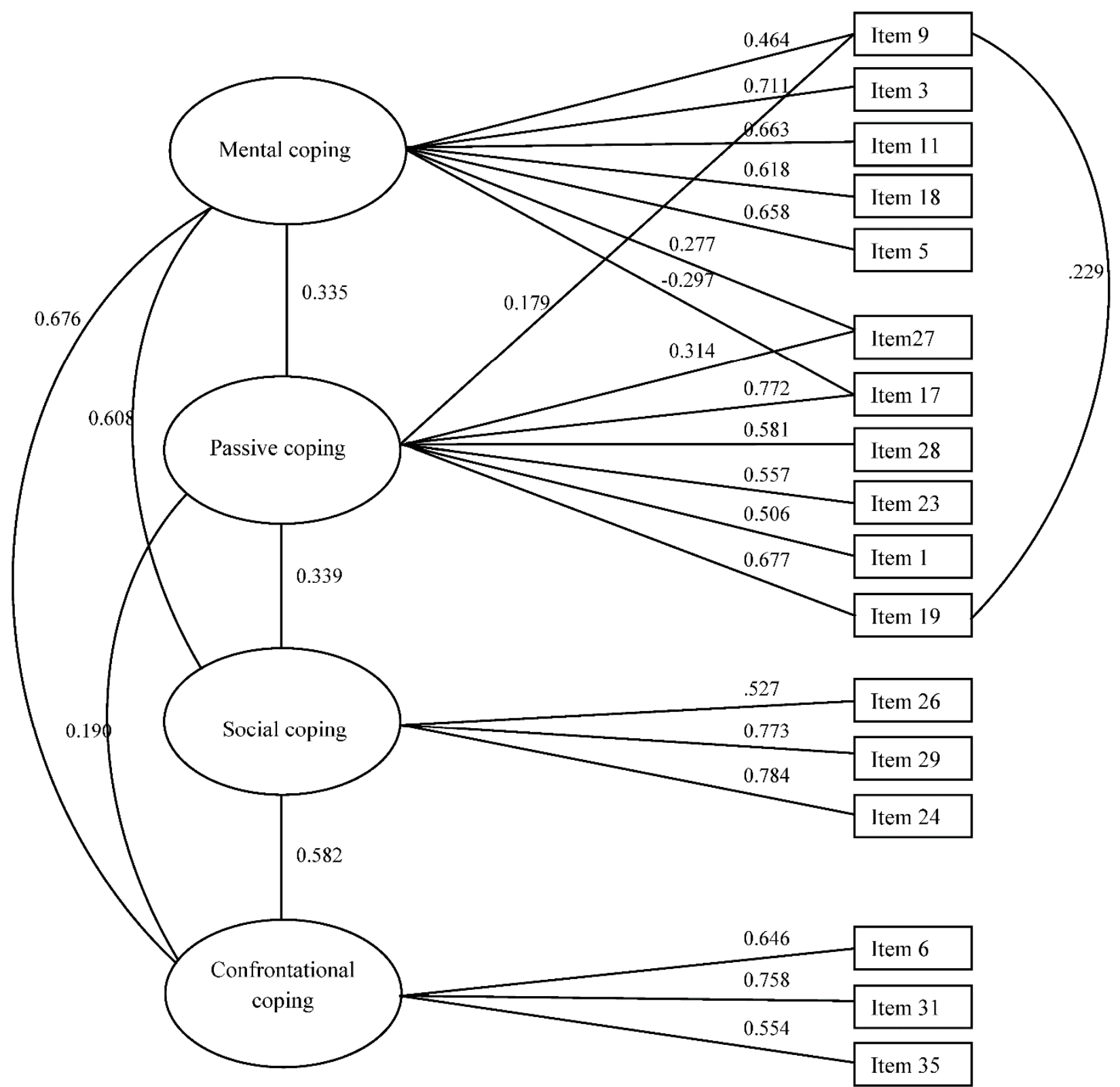

Figure 1. The final model displaying the factor structure of the Cyberbullying Coping Questionnaire including factor loadings.

\subsubsection{Discriminant Validity}

Evidence for discriminant validity was assessed for the four factors of the CCQ based on correlations with the RSE. Low correlations were expected and found: all factors of the CCQ correlated between $r=-0.10$ and $r=0.09$, which lie within the expected range. 


\section{Discussion}

Researchers have attempted to measure coping with (cyber)bullying, using different self-report questionnaires (SRQs) that assess coping. Many of these SRQs are subject to different shortcomings: there is a lack of consensus about coping categories, SRQs fail to distinguish between categorizations, and often they do not specifically assess coping with cyberbullying [34,41] due to the deviating contexts and appraisals online [1,22,32]. Despite the importance of context and appraisals [22,32,33], SRQs measure coping in general or are preceded with a definition of cyberbullying. In addition, they fail to see that online situations, contexts and appraisals, deviate from offline situations, which will lead to the selection of different coping strategies (e.g., online it is easier to be passive; you can close a window or shut down your computer). This study is therefore aimed to develop a SRQ, based on currently existing coping SRQs that are used in the (cyber)bullying literature, that specifically measures cyberbullying victims' coping strategies used in response to cyberbullying, and to formulate better fitting categorizations of coping strategies for cyberbullying. Consequently, the Cyberbullying Coping Questionnaire (CCQ) could be used in, for example, interventions that offer tailored advice to cyberbullying victims [108].

Although the initial model had to be adjusted based on modification indices, the evaluation of the final version (i.e., Figure 1) of the CCQ resulted in a four-factor model that fits the data well. The model has good internal consistency, acceptable test-retest reliability and good discriminant validity [34]. The development of the CCQ also fulfilled many of the recommendations from classical test-theory (see [34]): (1) the factor structure was determined with an oblique rotation; (2) the amount of extracting factors was determined with scree-tests in combination with parallel analysis; (3) factor loadings were at least 0.30; (4) the items of the CCQ seem to be clear and contain one statement, however, further research is needed to (further) determine the clarity and easiness of understanding; (5) with the final version of the CCQ consisting of 17 items, the recommendation of 10 participants per item was fulfilled; (6) factor structure was determined with a principal component analysis using oblique rotation, (7) the scree-test and parallel analysis determined the amount of extracting factors; and (8) factor loadings were at least 0.30 . We failed to include at least 500 participants, and although initially twice as many items as in the final version were included, the recommendation of four items per factor was not fulfilled: two factors consist of three items.

The four factors of the CCQ all included both cognitive and behavioral items, avoidance and approach items [26], and active and passive items. The CCQ thus appears to omit working in single (i.e., problem- versus emotion-focused) and topological (i.e., cognitive versus behavioral, avoid versus approach, active versus passive) categorizations [3,27], but includes these types of categorization in each factor. The first factor that was found, the mental coping categorization, appears to capture one's mental attempts to deal with, or solve, the cyberbullying. Three items in this categorization represent a focus on problem-solving (e.g., "I focus on solving the cyberbullying problem immediately"), which is associated with reductions in cyberbullying frequency and less health complaints and depression [4]. The other four items represent victims' awareness about the stressful situation and the mental attempt to control the stress by mentally disconnecting from, or changing the way, they perceive the situation (e.g., "I think that other people are experiencing things that are much worse"). Hence, with this categorization of coping strategies, the victim does not necessarily solve the cyberbullying, but tries to find ways to stop 
the bullying while trying not to get too upset about the cyberbullying event (i.e., it minimizes the painful impact of the stressful situation).

The second factor, the passive coping categorization, captures the way individuals manage cyberbullying events without actually solving the problem or trying to change the situation (e.g., "I ignore the bullies"). These items are possibly the only strategies one can use when situations appear to be uncontrollable. They are not necessarily negative; they appear to de-escalate and resolve the bullying [10]. Victims often recommend these strategies [37], but they are not always helpful [93]. Indeed, the victim fails at confronting the bully, and thus the use of the strategies in this categorization places the victim at risk for future victimization [5-12]. Furthermore, the use of such passive coping strategies is associated with more health complaints and depression than problem-solving coping [4], and the use of ineffective coping strategies appears to maintain online and offline bullying [5-12]. This is, however, an unavoidable categorization of coping; Parris et al., [26] suggested that any model that attempts to measure coping should also include inaction.

The confirmatory factor analysis (CFA) indicates that there are three items that load on both the mental and passive coping categorizations (e.g., "I try not to think about the cyberbullying", "I let the cyberbullying happen without reacting", "I think about fun things that are not related to cyberbullying"). These strategies appear to indicate an active and mental attempt not to think about the cyberbullying, but also indicate a tendency to be inactive and thus being passive. Similarly to the strategies of the passive coping categorization, these strategies do not solve the problem but probably will relieve stress, because the victim tries to reinterpret the situation. In addition, two items (i.e., "I try not to think about the cyberbullying" and "I act as if the cyberbullying did not happen") appear to be correlated: they both measure passive coping, however in a mental or behavioral way, respectively.

The third factor, the social coping categorization, constitutes actual behavior that one displays after being cyberbullied (e.g., "I ask someone (parent, teacher, friend, peer) for help"). These strategies are proactive because the victim actually tries to solve or cope with the problem in a constructive way, and these strategies are social because the victim uses his peer group. This strategy seems to strengthen the individual as well as solve the problem [34]. It is possible that a victim saves evidence in order (to be able) to show the actual behavior which is upsetting them when talking to someone else or asking for help.

The fourth and final factor, the confrontational coping categorization, appears to measure adolescents' strategies towards the cyberbully (e.g., "I tell the cyberbullies to stop"). Because the victim confronts the cyberbully with his or her behavior, for example by showing their irritation [10], these strategies can be interpreted as somewhat aggressive or as active but sometimes insufficient coping [92]. This strategy does not diminish the stress, however, it can help in solving the cyberbullying problem. Cyberbullies are often not aware of the consequences of their behavior because they consider the cyberbullying as an imaginary act of bullying (i.e., dissociative imagination [33]) or they are not confronted with the emotional reaction of the victim (i.e., the cockpit effect [121]). Hence, this coping categorization can lead to the discontinuation of cyberbullying by confronting the cyberbully with — and thus making him/her aware of - (the consequences of) his/her behavior.

This study is subjected to some strengths and limitations. A strength of this study is that the resulting SRQ omits single and topological categorizations [3,27]. These kinds of categorizations can result in too much heterogeneity among strategies [48] in which too many strategies (e.g., "I tell the cyberbullies to stop" and "I ask someone for help") are categorized into one coping factor (e.g., problem-solving 
coping), while they can be categorized in two factors (e.g., confrontational and social coping respectively). Therefore, it is highly likely that this SRQ will measure one's preferred coping strategies instead of measuring the extent in which contrasting coping strategies are used. In addition, this study found a four-factor (i.e., mental, passive, social and confrontational coping) structure with categorizations that are internally valid, theoretically meaningful, and that measures both cognitive versus behavioral and approach versus avoidance natured strategies. Furthermore, the CCQ is an adapted and modified version of coping measures that already exist [41]. Finally, many of the recommendations from classical test-theory (e.g., [34]) are fulfilled during the development.

This study also has some limitations. To begin with, the number of participants was low (i.e., 211), while classical test-theory suggests a minimum of 500 participants. Therefore, it is hard to assess construct validity and generalizability. Secondly, concurrent validity was not calculated as suggested [34]. Due to the length of the questionnaire, and the characteristics of the participant group (e.g., low educated, practical students who do not like to read) it was decided to keep the complete questionnaire as short as possible. Therefore, no additional SRQ that measures coping was used. Future studies should do this in order to establish concurrent validity. Thirdly, while performing factor analysis, several decisions (e.g., the number of factors to extract, the suitability of items for factor analysis) had to be made. This process has a certain subjectivity. Although not likely, it is possible that other researchers would have made different decision leading to a slightly different factor structure. Fourthly, the data used was part of an intervention study that aims to improve effective coping. Because the sample was relatively small, the second measurement of the experimental condition (i.e., at the second measurement 31 out of 68 participants had received the first out of three advice sessions in which they learned how to change irrational thoughts into rational thoughts [108]) was not excluded for the test-retest analysis. Without the experimental condition, the test-retest reliability only increased for the social coping factor (i.e., $\alpha$ 's were 0.89 for social, 0.62 for mental, 0.41 for passive, and 0.59 for confrontational coping), however $N$ was 37. Moreover, coping with cyberbullying was changed by the intervention only in the second and third session, and the second measurement came before the second session. Nevertheless, just to be sure, future studies should validate the test-retest part of this study (i.e., Figure 1) with data not obscured by an experimental design, and should take into account adolescents' opinions on meaningful and clear coping strategies, cultural backgrounds and developmental stages [41]. Finally, an assumption of this study was that online appraisals differ from offline appraisals, consequently leading to cyberbullying victims selecting different coping strategies compared to traditional bullying victims. However, this study did not explicitly measure appraisals. Future studies should also look into the appraisals of online victims of cyberbullying, and compare them with appraisals of offline victims.

In conclusion, this study seems to be a promising start in constructing a SRQ that measures coping with cyberbullying specifically. Many of the recommendations that come from classical test-theory were met, leading to a reliable and valid measure of coping. According to the results of this study, cyberbullying victims cope in a mental, passive, social or confrontational manner when faced with stress (i.e., cyberbullying). Among these categorizations are both cognitive and behavioral and approach and avoidance strategies instead of cognitive versus behavioral and approach versus avoidance strategies. This SRQ thus seems to treat coping as a multidimensional process in which strategies serve multiple functions, instead of the many existing SRQs that consider coping to consist of single or topological categorizations. 


\section{Author Contributions}

N.J. conceived of the study, conducted the preliminary study, recruited participants, conducted the analysis, and drafted the manuscript. N.J. and T.V. compared all items from the four selected adolescent coping SRQs with each other and merged and/or deleted items. F.D. controlled this process. F.D. and T.V. helped recruiting participants, helped to draft the manuscript and helped in drafting the final manuscript. L.L. supervised the whole research and helped with drafting and writing the final manuscript. N.J. processed all feedback from the other authors and reviewers. All authors read and approved of the final manuscript.

\section{Conflicts of Interest}

The authors declare no conflict of interest.

\section{References}

1. Lazarus, R.S.; Folkman, S. Stress, Appraisal, and Coping; Springer: New York, NY, USA, 1984.

2. Folkman, S.; Lazarus, R.S. An analysis of coping in a middle-aged community sample. J. Health Soc. Behav. 1980, 21, 219-239.

3. Skinner, E.A.; Edge, K.; Altman, J.; Sherwood, H. Searching for the structure of coping: A review and critique of category systems for classifying ways of coping. Psychol. Bull. 2003, 129, 216-269, doi:10.1037/0033-2909.129.2.216.

4. Völlink, T.; Bolman, C.A.W.; Eppingbroek, A.; Dehue, F. Emotion-Focused Coping Worsens Depressive Feelings and Health Complaints in Cyberbullied Children. J. Criminol. 2013, 2013, 1-10, doi:10.1155/2013/416976.

5. Andreou, E. Bully/Victim Problems and their Association with Coping Behaviour in Conflictual Peer Interactions Among School-age Children. Educ. Psychol. 2001, 21, 59-66, doi:10.1080/01443410125042.

6. Bijttebier, P.; Vertommen, H. Coping with peer arguments in school-age children with bully/victim problems. Br. J. Educ. Psychol. 1998, 68, 387-394.

7. Craig, W.; Pepler, D.; Blais, J. Responding to Bullying: What Works? Sch. Psychol. Int. 2007, 28, 465-477, doi:10.1177/0143034307084136.

8. Hunter, S.C.; Boyle, J.M.E. Appraisal and coping strategy use in victims of school bullying. Br. J. Educ. Psychol. 2004, 74, 83-107, doi:10.1348/000709904322848833.

9. Kristensen, S.M.; Smith, P.K. The use of coping strategies by Danish children classed as bullies, victims, bully/victims, and not involved, in response to different (hypothetical) types of bullying. Scand. J. Psychol. 2003, 44, 479-88.

10. Mahady Wilton, M.M.; Craig, W.M.; Pepler, D.J. Emotional Regulation and Display in Classroom Victims of Bullying: Characteristic Expressions of Affect, Coping Styles and Relevant Contextual Factors. Soc. Dev. 2000, 9, 227-245, doi:10.1111/1467-9507.00121.

11. Perry, D.G.; Hodges, E.V.E.; Egan, S.K.; Juvonen, J.; Graham, S. Determinants of chronic victimization by peers: A review and new model of family influence. In Peer Harass. Sch. Plight Vulnerable Vict; Guilford Press: New York, NY, USA, 2001; pp. 73-104. 
12. Skrzypiec, G.; Slee, P.; Murray-Harvey, R.; Pereira, B. School bullying by one or more ways: Does it matter and how do students cope? Sch. Psychol. Int. 2011, 32, 288-311, doi:10.1177/0143034311402308.

13. Kowalski, R.M.; Giumetti, G.W.; Schroeder, A.N.; Lattanner, M.R. Bullying in the digital age: A critical review and meta-analysis of cyberbullying research among youth. Psychol. Bull. 2014, 140, 1073-1137, doi:10.1037/a0035618.

14. Campbell, M.A.; Spears, B.; Slee, P.; Butler, D.; Kift, S. Victims' perceptions of traditional and cyberbullying, and the psychosocial correlates of their victimisation. Emot. Behav. Difficulties 2012, 17, 389-401, doi:10.1080/13632752.2012.704316.

15. Perren, S.; Dooley, J.; Shaw, T.; Cross, D. Bullying in school and cyberspace: Associations with depressive symptoms in Swiss and Australian adolescents. Child Adolesc. Psychiatry Ment. Health 2010, 4, 1-10, doi:10.1186/1753-2000-4-28.

16. Ybarra, M.L.; Mitchell, K.J. Youth engaging in online harassment: associations with caregiver-child relationships, Internet use, and personal characteristics. J. Adolesc. 2004, 27, 319-336, doi:10.1016/j.adolescence.2004.03.007.

17. Hinduja, S.; Patchin, J.W. Bullying, cyberbullying, and suicide. Arch. Suicide Res. 2010, 14, 206-221, doi:10.1080/13811118.2010.494133.

18. Schneider, S.K.; O’Donnell, L.; Stueve, A.; Coulter, R.W.S. Cyberbullying, school bullying, and psychological distress: A regional census of high school students. Am. J. Public Health 2012, 102, 171-177, doi:10.2105/AJPH.2011.300308.

19. Hinduja, S.; Patchin, J.W. Offline Consequences of Online Victimization. J. Sch. Violence 2007, 6, 89-112, doi:10.1300/J202v06n03_06.

20. Ortega, R.; Elipe, P.; Mora-Merchán, J.A.; Genta, M.L.; Brighi, A.; Guarini, A.; Smith, P.K.; Thompson, F.; Tippett, N. The emotional impact of bullying and cyberbullying on victims: A European cross-national study. Aggress. Behav. 2012, 38, 342-356, doi:10.1002/ab.21440.

21. Gradinger, P.; Strohmeier, D.; Spiel, C. Traditional bullying and cyberbullying: Identification of risk groups for adjustment problems. Z. Psychol. Psychol. 2009, 217, 205-213.

22. Ševčíková, A.; Šmahel, D.; Otavová, M. The perception of cyberbullying in adolescent victims. Emot. Behav. Difficulties 2012, 17, 319-328.

23. Van den Eijnden, R.; Vermulst, A.; van Rooij, T.; Meerkerk, G.J. Monitor Internet en Jongeren: Pesten op Internet en het Psychosociale Welbevinden van Jongeren; IVO: Rotterdam, The Netherlands, 2006. (In Dutch)

24. Black, C.; Wilson, G.T. Assessment of eating disorders: Interview versus questionnaire. Int. J. Eat. Disord. 1996, 20, 43-50.

25. Gravetter, F.J.; Forzano, L.B. Research Methods for the Behavioral Sciences; Wadsworth/Thomson Learning: Belmont, CA, USA, 2006.

26. Parris, L.; Varjas, K.; Meyers, J.; Cutts, H. High School Students' Perceptions of Coping With Cyberbullying. Youth Soc. 2011, 44, 284-306, doi:10.1177/0044118X11398881.

27. Compas, B.E.; Connor-Smith, J.K.; Saltzman, H.; Thomsen, A.H.; Wadsworth, M.E. Coping with stress during childhood and adolescence: Problems, progress, and potential in theory and research. Psychol. Bull. 2001, 127, 87-127, doi:10.1037//0033-2909.127.1.87.

28. Roth, S.; Cohen, L.J. Approach, avoidance, and coping with stress. Am. Psychol. 1986, 41, 813-819. 
29. Kochenderfer-Ladd, B.; Skinner, K. Children's coping strategies: Moderators of the effects of peer victimization? Dev. Psychol. 2002, 38, 267-278.

30. Šleglova, V.; Cerna, A. Cyberbullying in Adolescent Victims: Perception and Coping. Cyberpsychol. J. Psychosoc. Res. Cybersp. 2011, 5, Article 4. Available online: www.cyberpsychology.eu/view.php?cisloclanku=2011121901\&article $=4 \quad$ (accessed on 5 December 2013).

31. Völlink, T.; Bolman, C.A.W.; Dehue, F.; Jacobs, N.C.L. Coping with Cyberbullying: Differences Between Victims, Bully-victims and Children not Involved in Bullying. J. Community Appl. Soc. Psychol. 2013, 23, 7-24, doi:10.1002/casp.2142.

32. Vandebosch, H.; Van Cleemput, K. Cyberbullying among youngsters: Profiles of bullies and victims. New Media Soc. 2009, 11, 1349-1371, doi:10.1177/1461444809341263.

33. Kowalski, R.M.; Limber, S.P. Electronic Bullying Among Middle School Students. J. Adolesc. Health 2007, 41, S22-S30, doi:10.1016/j.jadohealth.2007.08.017.

34. Sveinbjornsdottir, S.; Thorsteinsson, E.B. Adolescent coping scales: A critical psychometric review. Scand. J. Psychol. 2008, 49, 533-548, doi:10.1111/j.1467-9450.2008.00669.x.

35. Van Ouytsel, J.; Walrave, M.; Vandebosch, H. Correlates of Cyberbullying and How School Nurses Can Respond. NASN Sch. Nurse 2014, doi:10.1177/1942602X13519477.

36. Noar, S.M.; Benac, C.N.; Harris, M.S. Does tailoring matter? Meta-analytic review of tailored print health behavior change interventions. Psychol. Bull. 2007, 133, 673-693.

37. Dehue, F.; Bolman, C.; Völlink, T. Cyberbullying: Youngsters" experiences and parental perception. Cyberpsychol. Behav. 2008, 11, 217-223, doi:10.1089/cpb.2007.0008.

38. Aricak, T.; Siyahhan, S.; Uzunhasanoglu, A.; Saribeyoglu, S.; Ciplak, S.; Yilmaz, N.; Memmedov, C. Cyberbullying among Turkish adolescents. Cyberpsychol. Behav. 2008, 11, 253-261, doi:10.1089/cpb.2007.0016.

39. Smith, P.; Mahdavi, J.; Carvalho, M.; Tippett, N. An investigation into cyberbullying, its forms, awareness and impact, and the relationship between age and gender in cyberbullying. Available online: http://webarchive.nationalarchives.gov.uk/20130401151715/http://www.education.gov.uk/ publications/eOrderingDownload/RBX03-06.pdf (accessed on 5 December 2013).

40. Jacobs, N.C.L.; Goossens, L.; Dehue, F.; Völlink, T.; Lechner, L. Dutch Cyberbullying Victims' Experiences, Perceptions, Attitudes and Motivations Related to (Coping with) Cyberbullying: Focus Group Interviews. Societies 2015, 5, 43-64, doi:10.3390/soc5010043.

41. Garcia, C. Conceptualization and measurement of coping during adolescence: A review of the literature. J. Nurs. Scholarsh 2010, 42, 166-185, doi:10.1111/j.1547-5069.2009.01327.x.

42. Naylor, P.; Cowie, H. The effectiveness of peer support systems in challenging school bullying: The perspectives and experiences of teachers and pupils. J. Adolesc. 1999, 22, 467-479, doi:10.1006/jado.1999.0241.

43. Kokkinos, C.M.; Antoniadou, N.; Dalara, E.; Koufogazou, A.; Papatziki, A. Cyber-Bullying, Personality and Coping among Pre-Adolescents. Int. J. Cyber Behav. Psychol. Learn. 2013, 3, 55-69, doi:10.4018/ijcbpl.2013100104.

44. Sharp, S. How much does bullying hurt? The effects of bullying on the personal wellbeing and educational progress of secondary aged students. Educ. Child Psychol. 1995, 12, 81-88. 
45. Martin, J.; Gillies, R.M. How Adolescents Cope With Bullying. Aust. J. Guid. Couns. 2004, 14, $195-210$.

46. Frydenberg, E.; Lewis, R. The Adolescent Coping Scale: Administrator's Manual; Australian Council for Educational Research: Melbourne, Australia, 1993.

47. Bijstra, J.O.; Jackson, S.; Bosma, H.A. De Utrechtse Coping Lijst voor Adolescenten. Kind En Adolesc. 1994, 15, 67-74.

48. Causey, D.L.; Dubow, E.F. Development of a self-report coping measure for elementary school children. J. Clin. Child Psychol. 1992, 21, 47-59.

49. Sandstrom, M.J. Pitfalls of the peer world: How children cope with common rejection experiences. J. Abnorm. Child Psychol. 2004, 32, 67-81.

50. Pozzoli, T.; Gini, G. Active Defending and Passive Bystanding Behavior in Bullying: The Role of Personal Characteristics and Perceived Peer Pressure. J. Abnorm. Child Psychol. 2010, 38, 815-827, doi:10.1007/s10802-010-9399-9.

51. Terranova, A.; Harris, J.; Kavetski, M.; Oates, R. Responding to Peer Victimization: A Sense of Control Matters. Child Youth Care Forum 2011, 40, 1-16, doi:10.1007/s10566-011-9144-8.

52. Spence, S.; De Young, A.; Toon, C.; Bond, S. Longitudinal examination of the associations between emotional dysregulation, coping responses to peer provocation, and victimisation in children. Aust. J. Psychol. 2009, 61, 145-155, doi:10.1080/00049530802259076.

53. Visconti, K.J.; Sechler, C.M.; Kochenderfer-Ladd, B. Coping with peer victimization: The role of children's attributions. Sch. Psychol. Q. 2013, 28, 122-140, doi:10.1037/spq0000014.

54. Shelley, D.; Craig, W.M. Attributions and Coping Styles in Reducing Victimization. Can. J. Sch. Psychol. 2009, 25, 84-100, doi:10.1177/0829573509357067.

55. Ayers, T.S.; Sandler, I.N. Manual for the Children's Coping Strategies Checklist and the How I Coped Under Pressure Scales. Available Online: http://prc.asu.edu/docs/CCSC-HICUPS\%20\% 20Manual2.pdf (accessed on 1 August 2014).

56. Kochenderfer-Ladd, B.; Pelletier, M.E. Teachers' views and beliefs about bullying: Influences on classroom management strategies and students' coping with peer victimization. J. Sch. Psychol. 2008, 46, 431-453, doi:10.1016/j.jsp.2007.07.005.

57. Kochenderfer-Ladd, B. Peer Victimization: The Role of Emotions in Adaptive and Maladaptive Coping. Soc. Dev. 2004, 13, 329-349, doi:10.1111/j.1467-9507.2004.00271.x.

58. Lam, C.W.C.; Frydenberg, E. Coping in the Cyberworld: Program Implementation and Evaluation-A Pilot Project. Aust. J. Guid. Couns. 2009, 19, 196-215.

59. Lodge, J.; Frydenberg, E. Cyber-Bullying in Australian Schools: Profiles of Adolescent Coping and Insights for School Practitioners. Aust. Educ. Dev. Psychol. 2007, 24, 45-58.

60. Murray-harvey, R.; Skrzypiec, G.; Slee, P.T. Effective and Ineffective Coping With Bullying Strategies as Assessed by Informed Professionals and Their Use by Victimised Students. Aust. J. Guid. Couns. 2012, 22, 122-138, doi:10.1017/jgc.2012.5.

61. Lodge, J. Exploring the measurement and structure of children's coping through the development of a short form of coping. Aust. Educ. Dev. Psychol. 2006, 23, 35-45.

62. Waasdorp, T.E.; Bagdi, A.; Bradshaw, C.P. Peer Victimization Among Urban, Predominantly African American Youth: Coping With Relational Aggression Between Friends. J. Sch. Violence 2009, 9, 98-116, doi:10.1080/15388220903341372. 
63. Southam-gerow, K.L.; Goodman, M.A. The regulating role of negative emotions in children's coping with peer rejection. Child Psychiatry Hum. Dev. 2010, 41, 515-534, doi:10.1007/s10578010-0185-2.

64. Amirkhan, J.H. A factor analytically derived measure of coping: The Coping Strategy Indicator. J. Pers. Soc. Psychol. 1990, 59, 1066-1074, doi:10.1037//0022-3514.59.5.1066.

65. Palladino, B.E.; Nocentini, A.; Menesini, E. Online and offline peer led models against bullying and cyberbullying. Psicothema 2012, 24, 634-639.

66. Garnefski, N.; Rieffe, C.; Jellesma, F.; Terwogt, M.M.; Kraaij, V. Cognitive emotion regulation strategies and emotional problems in 9-11-year-old children: The development of an instrument. Eur. Child Adolesc. Psychiatry 2007, 16, 1-9.

67. Jellesma, F.C.; Verhulst, A.F.; Utens, E.M.W.J. Cognitive coping and childhood anxiety disorders. Eur. Child Adolesc. Psychiatry 2010, 19, 143-150, doi:10.1007/s00787-009-0051-6.

68. Garnefski, N.; Kraaij, V.; Spinhoven, P. Negative life events, cognitive emotion regulation and emotional problems. Pers. Individ. Dif. 2001, 30, 1311-1327, doi:10.1016/S0191-8869(00)00113-6.

69. Ayers, T.S.; Sandier, I.N.; West, S.G.; Roosa, M.W. A Dispositional and Situational Assessment of Children's Coping: Testing Alternative Models of Coping. J. Pers. 1996, 64, 923-958.

70. Zimmer-Gembeck, M.J.; Lees, D.; Skinner, E.A. Children's emotions and coping with interpersonal stress as correlates of social competence. Aust. J. Psychol. 2011, 63, 131-141, doi:10.1111/j.1742-9536.2011.00019.x.

71. Hampel, P.; Dickow, B.; Petermann, F. Reliability and validity of the German Coping Questionnaire for Children and Adolescents (Ger-man). Z. Diff. Diagn. Psychol. 2002, 23, 273-289.

72. Hampel, P.; Manhal, S.; Hayer, T. Direct and relational bullying among children and adolescents: Coping and psychological adjustment. Sch. Psychol. Int. 2009, 30, 474-490, doi:10.1177/0143034309107066.

73. Roger, D.; Jarvis, G.; Najarian, B. Detachment and coping: The construction and validation of a new scale for measuring coping strategies. Pers. Individ. Dif. 1993, 15, 619-626.

74. Grennan, S.; Woodhams, J. The impact of bullying and coping strategies on the psychological distress of young offenders. Psychol. Crime Law 2007, 13, 487-504, doi:10.1080/10683160601060598.

75. Halstead, M.; Johnson, S.B.; Cunningham, W. Measuring Coping in Adolescents: An Application of the Ways of Coping Checklist. J. Clin. Child. Psychol. 1993, 22, 337-344, doi:10.1207/s15374424jccp2203_4.

76. Dise-Lewis, J.E. The Life Events and Coping Inventory: An assessment of stress in children. Psychosom. Med. 1988, 50, 484-499.

77. Olafsen, R.N.; Viemerö, V. Bully/victim problems and coping with stress in school among 10- to 12-year-old pupils in Åland, Finland. Aggress. Behav. 2000, 26, 57-65, doi:10.1002/(sici)10982337(2000)26:1<57::aid-ab5>3.0.co;2-i.

78. Lodge, J.; Feldman, S.S. Avoidant coping as a mediator between appearance-related victimization and self-esteem in youn Asutralian adolescents. Br. J. Dev. Psychol. 2007, 25, $633-642$. 
79. Cassidy, T.; Long, C. Problem-solving style, stress and psychological illness: Development of a multifactorial measure. Br. J. Clin. Psychol. 1996, 35, 265-277.

80. Cassidy, T.; Taylor, L. Coping and psychological distress as a function of the bully victim dichotomy in older children. Soc. Psychol. Educ. 2005, 8, 249-262.

81. Carver, C.S.; Scheier, M.F.; Weintraub, J.K. Assessing coping strategies: A theoretically based approach. J. Pers. Soc. Psychol. 1989, 56, 267-283, doi:10.1037/0022-3514.56.2.267.

82. Newman, M.L.; Holden, G.W.; Delville, Y. Coping With the Stress of Being Bullied: Consequences of Coping Strategies Among College Students. Soc. Psychol. Personal. Sci. 2010, doi:10.1177/1948550610386388.

83. Folkman, S.; Lazarus, R.S. If it changes it must be a process: Study of emotion and coping during three stages of a college examination. J. Pers. Soc. Psychol. 1985, 48, 150-170.

84. Remillard, A.M.; Lamb, S. Adolescent Girls' Coping With Relational Aggression. Sex Roles 2005, 53, 221-229, doi:10.1007/s11199-005-5680-8.

85. Salmivalli, C.; Karhunen, J.; Lagerspetz, K.M.J. How do the victims respond to bullying? Aggress. Behav. 1996, 22, 99-109, doi:10.1002/(SICI)1098-2337(1996)22:2<99::AID-AB3>3.0.CO;2-P.

86. Puhl, R.M.; Luedicke, J. Weight-based victimization among adolescents in the school setting: Emotional reactions and coping behaviors. J. Youth Adolesc. 2012, 41, 27-40, doi:10.1007/s10964-011-9713-z.

87. Harper, C.R.; Parris, L.N.; Henrich, C.C.; Varjas, K.; Meyers, J. Peer Victimization and School Safety: The Role of Coping Effectiveness. J. Sch. Violence 2012, 11, 267-287, doi:10.1080/15388220.2012.706876.

88. Tenenbaum, L.S.; Varjas, K.; Meyers, J.; Parris, L. Coping strategies and perceived effectiveness in fourth through eighth grade victims of bullying. Sch. Psychol. Int. 2011, 32, 263-287, doi:10.1177/0143034311402309.

89. Machmutow, K.; Perren, S.; Sticca, F.; Alsaker, F.D. Peer victimisation and depressive symptoms: Can specific coping strategies buffer the negative impact of cybervictimisation? Emot. Behav. Difficulties 2012, 17, 403-420, doi:10.1080/13632752.2012.704310.

90. Machmutow, K.; Perren, S. Coping with cyberbullying: Successful and unsuccessful coping strategies. Poster presented at the 3rd COST workshop on cyberbullying, Turku, Finland, 13 May 2011.

91. Jäger, T.; Jäger, R.S. LAPSuS: Landauer Anti-Gewalt-Programm für Schülerinnen und Schüler; Zentrum für Empirische Pädagogische Forschung: Landau, Germany, 1996. (In German)

92. Riebel, J.; Jäger, R.S.; Fischer, U.C. Cyberbullying in Germany-An exploration of prevalence, overlapping with real life bullying and coping strategies. Psychol. Sci. Q. 2009, 51, 298-314.

93. Machackova, H.; Cerna, A.; Sevcikova, A.; Dedkova, L.; Daneback, K. Effectiveness of coping strategies for victims of cyberbullying. Cyberpsychol. J. Psychosoc. Res. Cybersp. 2013, 7, Article 5. Available online : http://www.cyberpsychology.eu/view.php?cisloclanku=2014012101\&article=5 (accessed on 30 July 2014).

94. Perren, S.; Corcoran, L.; Cowie, H.; Dehue, F.; Garcia, D.; Mc Guckin, C. Cyberbullying and traditional bullying in adolescence: Differential roles of moral disengagement, moral emotions, and moral values. Eur. J. Dev. Psychol. 2012, 9, 195-209. 
95. Hunter, S.C.; Boyle, J.M.E.; Warden, D. Help seeking amongst child and adolescent victims of peer-aggression and bullying: The influence of school-stage, gender, victimisation, appraisal, and emotion. Br. J. Educ. Psychol. 2004, 74, 375-390, doi:10.1348/0007099041552378.

96. Patchin, J.W.; Hinduja, S. Bullies Move Beyond the Schoolyard: A Preliminary Look at Cyberbullying. Youth Violence Juv. Justice 2006, 4, 148-169, doi:10.1177/1541204006286288.

97. Price, M.; Dalgleish, J. Cyberbullying: Experiences, impacts and coping strategies as described by Australian young people. Youth Stud. Aust. 2010, 29, 51-59.

98. Hunter, S.C.; Mora-Merchan, J.; Ortega, R. The Long-Term Effects of Coping Strategy Use in Victims of Bullying. Span. J. Psychol. 2004, 7, 3-12.

99. Kanetsuna, T.; Smith, P.K. Pupil Insights into Bullying, and Coping with Bullying-A Bi-National Study in Japan and England. J. Sch. Violence 2002, 1, 5-29.

100. Smith, P.K.; Shu, S. What Good Schools can Do About Bullying: Findings from a Survey in English Schools After a Decade of Research and Action. Childhood 2000, 7, 193-212, doi:10.1177/0907568200007002005.

101. Hunter, S.C.; Boyle, J.M.E. Perceptions of control in the victims of school bullying: The importance of early intervention. Educ. Res. 2002, 44, 323-336.

102. Naylor, P.; Cowie, H.; Rey, R. Coping strategies of secondary school children in response to being bullied. Child Adolesc. Ment. Health 2001, 6, 114-120.

103. Schenk, A.M.; Fremouw, W.J. Prevalence, Psychological Impact, and Coping of Cyberbully Victims Among College Students. J. Sch. Violence 2012, 11, 21-37, doi:10.1080/15388220.2011.630310.

104. Elledge, L.C.; Cavell, T.A.; Ogle, N.T.; Newgent, R.A.; Faith, M.A. History of peer victimization and children's response to school bullying. Sch. Psychol. Q. 2010, 25, 129-141, doi:10.1037/a0020313.

105. Kochenderfer, B.J.; Ladd, G.W. Victimized children's responses to peers' aggression: Behaviors associated with reduced versus continued victimization. Dev. Psychopathol. 1997, 9, 59-73, doi:10.1017/S0954579497001065.

106. Garnefski, V.; Kraaij, N.; Spinhoven, P. Manual for the Use of the Cognitive Emotion Regulation Questionnaire; DATEC: Leidorp, The Netherlands, 2002.

107. Jacobs, N.C.L.; Völlink, T.; Dehue, F.; Lechner, L. Procesevaluatie van Online Pestkoppenstoppen; Open University: Heerlen, The Netherlands, 2014. (In Dutch)

108. Jacobs, N.C.L.; Völlink, T.; Dehue, F.; Lechner, L. Online Pestkoppenstoppen: Systematic and theory-based development of a web-based tailored intervention for adolescent cyberbully victims to combat and prevent cyberbullying. BMC Public Health 2014, 14, 396, doi:10.1186/1471-245814-396.

109. Conway, J.M.; Huffcutt, A.I. A review and evaluation of exploratory factor analysis practices in organizational research. Organ Res. Methods 2003, 6, 147-168.

110. Field, A. Discovering Statistics Using SPSS, 3rd ed.; SAGE Publications Limited: Los Angeles, CA, USA; London, UK; New Delhi, India; Singapore, Singapore; Washington, DC, USA, 2009.

111. Rosenberg, M. Conceiving the Self; Basic Books: New York, NY, USA, 1979.

112. Tabachnick, B.G.; Fidell, L.S. Using Multivariate Statistics, 5th ed.; Allyn \& Bacon: Boston, MA, USA, 2007. 
113. Linting, M.; van der Kooij, A. Nonlinear principal components analysis with CATPCA: A tutorial. J. Pers. Assess. 2012, 94, 12-25, doi:10.1080/00223891.2011.627965.

114. Linting, M.; Meulman, J.J.; Groenen, P.J.F.; van der Koojj, A.J. Nonlinear principal components analysis: Introduction and application. Psychol. Methods 2007, 12, 336-358, doi:10.1037/1082989X.12.3.336.

115. Kline, P. An Easy Guide to Factor Analysis; Routledge: London, UK, 1994.

116. Jackson, D.L.; Gillaspy, J.A.; Purc-Stephenson, R. Reporting practices in confirmatory factor analysis: An overview and some recommendations. Psychol. Methods 2009, 14, 6-23, doi:10.1037/a0014694.

117. Kenny, D.A. Measuring Model Fit 2012. Available online: http://davidakenny.net/cm/fit.htm (accessed on 2 July 2014).

118. Bollen, K.A. Structural Equations with Latent Variables; John Wiley \& Sons: New York, NY, USA, 1989.

119. Arbuckle, J.L. Amos 20 User's Guide; IBM: Chicago, IL, USA, 2001.

120. Tabachnick, B.G.; Fidell, L.S. Using Multivariate Statistics, 4th ed.; Allyn \& Bacon: Boston, MA, USA, 2001.

121. Heirman, W.; Walrave, M. Assessing Concerns and Issues about the Mediation of Technology in Cyberbullying. Cyberpsychol. J. Psychosoc. Res. Cybersp. 2008, 2, 1-12.

(C) 2015 by the authors; licensee MDPI, Basel, Switzerland. This article is an open access article distributed under the terms and conditions of the Creative Commons Attribution license (http://creativecommons.org/licenses/by/4.0/). 